DOI: 10.14526/2070-4798-2019-14-3-55-58

\title{
The impact of unified handball on the level of general physical training and psychosocial adaptation among 13-14 year-old pupils with mild mental retardation
}

\author{
Aleksandr V. Dorontsev ${ }^{1 *}$, Anastasiya A. Svetlichkina ${ }^{1}$, Nina A. Zinchuk ${ }^{2}$, \\ Natalya A. Yermolina ${ }^{2}$ \\ ${ }^{1}$ Astrakhan State Medical University \\ Astrakhan, Russia \\ ORCID: oooo-0oo1-9446-103X, aleksandr.doroncev@rambler.ru* \\ ORCID: oooo-0oo1-6337-6935, doronceva@rambler.ru \\ ${ }^{2}$ Astrakhan State University \\ Astrakhan, Russia \\ ORCID: 0ooo-ooo1-9228-748X, tomara-72_64@mail.ru \\ ORCID: 00oo-0oo1-5837-9912, niva-zinchuk@mail.ru
}

\begin{abstract}
The tested method of unified handball training sessions organization involving volunteers - students of higher educational establishments allowed to reveal positive impact of adaptive sports not only on physical readiness of experiment participants, but also on their psychosocial rehabilitation. It is interesting to study communicative qualities development among schoolchildren during classes with volunteers-students. With the number of classes increase the level of interpersonal contacts also increased exponentially, the level of tension during new motor actions mastering decreased. Materials. The material for the study formed the results of students' physical readiness in a boarding school for children with LHO (Limited health opportunities) № 1 in Astrakhan (21 people, age - 13 - 14 years-old). All pupils had the following diagnosis: easy adjustable degree of mental retardation, there were no other reasons for physical education and adaptive sports restriction. Research methods. Criteria included into the study: complex analysis of physical qualities development; the level of schoolchildren's psychosocial adaptation analysis (based on a joint questionnaire organization among parents and schoolchildren); voluntary participation in the study (unified handball lessons), the decision on the activities was made by parents and guardians. Criteria of exclusion: pupils who previously went in for adaptive sports - game types. All students underwent an annual medical examination, assessment of the risk factors of disadaptive reactions development to physical load was determined by the results of functional samples. The initial level of physical qualities development was assessed on the basis of the control normatives of the Federal State Educational Standard for Secondary Schools. Initially, the experimental group $(\mathrm{n} 1=10)$ and the control group $(\mathrm{n} 2=11)$ were formed. The groups didn't have considerable differences in gender, age and physical readiness. Statistical processing of the results was carried out using standard methods of variation statistics (the USA Statistica 10). The validity of the differences was evaluated by Student 's t-criterion. Distinctions were considered reliable in case $p<0.05$. The correlation analysis was realized with Pearson correlation coefficient. Results. There was a steady increasing indices of physical readiness and psychosocial adaptation. Conclusion. The use of unified handball elements in a group of students with a corrected intelligence disorder allows to form the corresponding level of physical and communicative qualities development necessary for adaptive sports lessons.
\end{abstract}

Keywords: unified handball, students, adjustable intellect disorder.

For citation: Aleksandr V. Dorontsev*, Anastasiya A. Svetlichkina, Nina A. Zinchuk, Natalya A. Yermolina. The impact of unified handball on the level of general physical training and psychosocial adaptation among 13-14 year-old pupils with mild mental retardation. Russian Journal of Physical Education and Sport. 2019; 14(3): 55-58. DOI: 10.14526/2070-4798-2019-14-3-55-58

\section{INTRODUCTION}

Adaptive physical culture studies and, in particular, concerning adaptivesports attractnotonly the specialists in the sphere of physical culture and sport, but also teachers, psychologists, physiologists, speech pathologists, doctors and other specialists [2;
3]. The most progressive methodologies of training were mastered and successfully used. Special Olympic Games organization provides people with mental retardation with the conditions for going in for sports and physical culture in any age. More than one million of people from 162 countries take part 
in them.

Special Olympic Games form the most popular sports movement of this kind, as they are available and developing. This kind of sports competitions include unified handball $[4,7,6,8]$. Research workers $[1,5,9,10]$ mention great practical significance, value and necessity of adaptive physical culture and sport lessons for people with LHO (Limited health opportunities). In this connection we studied the use of unified handball elements in the group of 1314 year-old students at a boarding school № 1 in Astrakhan with mild mental retardation diagnosis.

\section{MATERIALS AND METHODS}

During the work we analyzed the results of physical readiness level of students, the results of functional tests, the dynamics of physical qualities development. Communicative skills development was defined by the questionnaire survey in which both parents and students took part.

\section{RESULTS AND DISCUSSION}

The results of the initial control normatives in the examined groups didn't reveal considerable differences in students' physical readiness level. The implementation of power standards did not cause any difficulties among $56 \pm 5.2 \%$ of students, a satisfactory level of flexibility was revealed among $39 \pm 3.7 \%$ of the respondents. The endurance test caused difficulty among $86 \pm 4.1 \%$ of schoolchildren, unsatisfactory results of speed qualities development $88 \pm 2.7 \%$ and coordination abilities $93 \pm 2.5 \%$ were revealed among children at the initial stage of the study. In order to solve the main tasks of the presented work at the preliminary stage, a survey among parents and guardians was carried out. The questionnaire consisted of three blocks, each block included five questions. The first block of the questionnaire allowed defining the attitude of parents and guardians to systematic adaptive sport lessons. The second block of questions was directed toward the level of a child's communicative qualities development. The third block of questions related to the possibility of cooperating adaptive physical culture and sports activities with children. Parents and children answered the questions together, the result of the answers at the beginning of the study revealed the following priorities:

- according to the first block of questions most parents and guardians were for the physical culture lessons in a form of "for own development" $76 \%$, $11 \%$ of the respondents were positive concerning adaptive sport and $13 \%$ didn't consider additional adaptive sport lessons necessary in a day regime. According to the second block of questions more than $50 \%$ of respondents were for a positive influence of physical culture and sport on children's communicative qualities development, more than
$20 \%$ of parents and guardians considered priority kinds of communicative qualities among children sports games and $26 \%$ of the respondents expressed uncertainty in the benefit of physical culture and sport lessons. According to the third block of questions more than 50\% of respondents were positive concerning the question of cooperative adaptive physical culture lessons with children, 30\% of the respondents expresses the desire to train with children, but didn't have opportunities for it and less than $20 \%$ of respondents were not sure in the benefit of cooperating lessons with children. At the end of the held research work there were considerable changes in the answers of the respondents. In the first block of questions almost all parents and guardians were for additional adaptive physical culture lessons, unchanged was the format of "for own benefit" lessons, at the same time all children were for the participation in the competitions. According to the second block of questions all respondents mentioned positive changes in children's communicative qualities development (among those, who go in for unified handball), the number of contacts with volunteers increased, there appeared the desire to master the ball "like a coach". At the same time all respondents mentioned the interest of children in a competitive variant of the lessons organization. According to the third block of questions all respondents gave affirmative answers concerning unified handball cooperating lessons with children. The dynamics of psycho-emotional adaptation of children to cooperating training with volunteers and parents is of great interest. At the first stages of training, children who trained with volunteers showed some uncertainty in tasks fulfillment, children were unsociable, but during the second month of classes there was a significant change in communication with volunteers, the use of game elements of unified handball allowed to improve the communicative skills of children.

The dynamics study of physical qualities development during the research in the experimental group $(\mathrm{n} 1=10)$ helped to reveal a significant increase of coordination abilities and speed - power qualities. No significant changes were observed in the control group (n2 = 11), where physical culture was within the school program (table).

Autocorrelation function coefficients obtained in the course of mathematical processing made it possible to conclude that there is a significant role of training elements of unified handball and physical qualities development $r=0,477 ; p<0,05$.

Elements of unified handball used for training with students of the experimental group $(n 1=10)$ characterized by not high level of physical qualities development, are available and quite effective. The applied elements of unified handball, which were used for lessons: 

shot;

- targeted pass, ball dribuling 10 meters, point

- speed pass;

- ball dribbling according to set trajectory;

- ball taking with the indirect pass in movement;

- goal attack with the indirect pass;

- ball throwing at the distance in the mentioned corridor.

It should be noted that all exercises were fulfilled in pairs with parents or volunteers. Before the task fulfillment parents and volunteers demonstrated the exercises with the elements and in a complex.

\begin{tabular}{|c|c|c|c|c|c|c|c|c|c|c|c|c|}
\hline \multirow[t]{2}{*}{ Indices } & \multicolumn{2}{|c|}{$\begin{array}{l}\text { The Initial } \\
\text { testing }\end{array}$} & \multicolumn{2}{|c|}{$\begin{array}{l}\text { I point of } \\
\text { control in } 2 \\
\text { months }\end{array}$} & \multicolumn{2}{|c|}{$\begin{array}{l}\text { II point control } \\
\text { in } 4 \text { months }\end{array}$} & \multicolumn{2}{|c|}{$\begin{array}{c}\text { III point of } \\
\text { control in } 6 \\
\text { months }\end{array}$} & \multicolumn{2}{|c|}{$\begin{array}{l}\text { IV point of } \\
\text { control in } 8 \\
\text { months }\end{array}$} & \multicolumn{2}{|c|}{$\begin{array}{l}\text { Control } \\
\text { testing } \\
\text { in } 9 \\
\text { months }\end{array}$} \\
\hline & $\mathrm{n}_{1}-10$ & $\mathrm{n}_{2}-11$ & $\mathrm{n}_{1}-10$ & $\mathrm{n}_{z}-11$ & $\mathrm{n}_{1}-10$ & $\mathrm{n}_{z}-11$ & $\mathrm{n}_{1}-10$ & $\mathrm{n}_{\mathrm{y}}-11$ & $n_{1}-10$ & $\mathrm{n}_{2}-11$ & $\begin{array}{l}\mathrm{n}_{\mathrm{r}^{-}} \\
10\end{array}$ & $\begin{array}{l}\mathrm{n}_{r} \\
11\end{array}$ \\
\hline \begin{tabular}{|l} 
1. Shuttle \\
running \\
$13 \times 10$ \\
(seconds)
\end{tabular} & $\begin{array}{l}12,4=1, \\
5\end{array}$ & $\begin{array}{l}12,7 \pm 1, \\
2\end{array}$ & $\begin{array}{l}12,1 \pm \\
1,4\end{array}$ & $\begin{array}{l}12,5 \pm 1, \\
3\end{array}$ & $\begin{array}{l}11,2 \pm 1 . \\
4\end{array}$ & $12.7 \pm 1.2$ & $\begin{array}{l}10.9 \pm 1, \\
1\end{array}$ & $\begin{array}{l}12,3=1, \\
4\end{array}$ & $\begin{array}{l}10,1 \pm 1 \\
.1\end{array}$ & $\begin{array}{l}12,5 \pm \\
1,3\end{array}$ & $\begin{array}{l}10,2 \\
=1,1\end{array}$ & $\begin{array}{l}12= \\
1,2\end{array}$ \\
\hline $\begin{array}{l}\text { 2. } 60 \text { meters } \\
\text { running } \\
\text { (seconds) }\end{array}$ & $\begin{array}{l}11,7 \pm 0, \\
9\end{array}$ & $\begin{array}{l}11,5 \pm 1, \\
1\end{array}$ & $\begin{array}{l}11,9 \pm \\
1,1\end{array}$ & $\begin{array}{l}11,7 \pm 1, \\
4\end{array}$ & $\begin{array}{l}11,2 \pm 1, \\
1\end{array}$ & $11,8 \pm 1,2$ & $\begin{array}{l}10,4 \pm 0, \\
9\end{array}$ & $\begin{array}{l}11,4=1, \\
1\end{array}$ & $\begin{array}{l}10,3 \pm 0 \\
.8\end{array}$ & $\begin{array}{l}11,5 \pm \\
1,1\end{array}$ & $\begin{array}{l}10,3 \\
=0,9\end{array}$ & $\begin{array}{l}11,4 \\
=1,2\end{array}$ \\
\hline $\begin{array}{l}3 . \\
\text { "Swallow" } \\
\text { exercise } \\
\text { (seconds) }\end{array}$ & $9,7 \pm 4,2$ & $9,5 \pm 1,1$ & $\begin{array}{l}10,3 \pm \\
0.9\end{array}$ & $9,7 \pm 1,0$ & $\begin{array}{l}12,5 \pm 1 \\
4\end{array}$ & $9,9 \pm 1,2$ & $\begin{array}{l}18,2 \pm 1, \\
1\end{array}$ & $9,7 \pm 1,4$ & $\begin{array}{l}18,0 \pm 1 \\
.3\end{array}$ & $\begin{array}{l}9,5=1, \\
5\end{array}$ & $\begin{array}{l}18,1 \\
=1,1\end{array}$ & $\begin{array}{l}9,7 \pm \\
1,4\end{array}$ \\
\hline $\begin{array}{l}4 . \text { Chin ups at } \\
\text { a high bar } \\
\text { boys } \\
\text { (amount of } \\
\text { repetitions) }\end{array}$ & $6 \pm 2,5$ & $5 \pm 1,8$ & $6=2,5$ & $5 \pm 2.0$ & $6=2,8$ & $5 \pm 2,5$ & $6 \pm 2,4$ & $5 \pm 1,0$ & $6=2,5$ & $5=1,8$ & $\begin{array}{l}6 \pm 2, \\
5\end{array}$ & $\begin{array}{l}5 \pm 2, \\
5\end{array}$ \\
\hline $\begin{array}{l}\text { 5.Dip up at a } \\
\text { gymnastic } \\
\text { bench } \\
\text { girls } \\
\text { (amount } \\
\text { repetitions) }\end{array}$ & $5 \pm 1,2$ & $5,6 \pm 1,4$ & $\begin{array}{l}5,7=1, \\
2\end{array}$ & $5 \pm 1,0$ & $6.2 \pm 1,4$ & $5,6 \pm 1,2$ & $6,8=1,2$ & $5,2 \pm 1,4$ & $\begin{array}{l}7,2 \pm 1, \\
2\end{array}$ & $\begin{array}{l}5,6=1, \\
4\end{array}$ & $\begin{array}{l}7,2 \pm \\
1,2\end{array}$ & $\begin{array}{l}5,6 \pm \\
1,2\end{array}$ \\
\hline $\begin{array}{l}\text { 6.skipping } \\
\text { within } 20 \\
\text { seconds } \\
\text { (amount of } \\
\text { repetitions) }\end{array}$ & $\begin{array}{l}19,2=5, \\
4\end{array}$ & $\begin{array}{l}20,1 \pm 5, \\
2\end{array}$ & $\begin{array}{l}22 \pm 4, \\
6\end{array}$ & $\begin{array}{l}20,6 \pm 5, \\
4\end{array}$ & $26 \pm 6,1$ & $22,4 \pm 5,0$ & $28=4,2$ & $\begin{array}{l}24,4=5, \\
0\end{array}$ & $30 \pm 6,2$ & $\begin{array}{l}24,1= \\
4,2\end{array}$ & $\begin{array}{l}30 \pm \\
4.4\end{array}$ & $\begin{array}{l}23= \\
2,6\end{array}$ \\
\hline $\begin{array}{l}\text { 7. Standing } \\
\text { long-jump } \\
\text { (cm) }\end{array}$ & $142 \pm 15$ & $140=10$ & ${ }_{2}^{145 \pm 1}$ & $144=11$ & $150 \pm 10$ & $143=10$ & $150=10$ & $145=10$ & $\begin{array}{l}154=1 \\
0\end{array}$ & $\begin{array}{l}143 \pm 1 \\
1\end{array}$ & $\begin{array}{l}158 \\
=8\end{array}$ & $\begin{array}{r}144 \pm \pm \\
10\end{array}$ \\
\hline
\end{tabular}

Note: ${ }^{*} \mathrm{p}<0,05$ in comparison with the control group.

\section{CONCLUSION}

Thus, studying the application of unified handball elements in the group of schoolchildren who have corrected disorder of intellect, showed the diversity of positive shifts in psychosocial rehabilitation, the level of physical development and regulatoryadaptive processes development. The main criteria and regularities determination of physical qualities development using of unified handball elements in practice of adaptive physical culture in terms of this disorder among children, would help to create the conditions for perspective adaptive sport development.

\section{REFERENCES}

1. Aptsiauri L.Sh. Sport as social phenomenon and the factor of personality socialization. Teoriya I praktika fizicheskoj kul'tury = Theory and practice of physical culture. 2003; 1: 12-14 (In Russ., In
Engl.).

2. Venevtsev S.I. Adaptivnyj sport dlya lic $\mathrm{s}$ narusheniem intellekta: metodicheskoe posobie [Adaptive sport for people with intellect disorders: methodical manual]. Moscow: Soviet sport. 2006: 56 (In Russ.).

3. Guskov S. I. Sport I osobye deti [Sport and special children]. Moscow: Vagrius. 2015: 303 (In Russ.).

4. Zdravoohranenie v Rossii: Statisticheskij sbornik [Health care in Russia: Statistical collection of works]. Moscow: State committee of statistics of Russia. 2018: 356 (In Russ.).

5. Markov L.N. Clinical aspects of sports medicine. Teoriya I praktika fizicheskoj kul'tury = Theory and practice of physical culture. 2014; 5: 41 (In Russ., In Engl.).

6. Polozhenie o provedenii sorevnovanij po yunifajt gandbollu [Thesis of unified handball 
competitions organization]. (Official thesis of unified handball tournament in Moscow). Moscow. 2017: 4 (In Russ.).

7. Polozhenie o provedenii Spartakiady Special'noj Olimpiady Rossii po letnim vidam sporta [Thesis of Summer sports Special Olympiade of Russia organization] (adopted by the Ministry of sport of the Russian Federation and All-Russian social charity organization of helping disabled people with mental retardatiuon "Special Olympiade of Russia" August, 26, 2016) URL: http://base. garant.ru/57419881/ (In Russ.)

8. Svetlichkina A.A., Chichkova M.A. The work of cardiovascular system estimation among people with the restricted auditory abilities. Kardiologiya I kardihirurgiya: innovacionnye resheniya 2016 Materialy yubilejnoj 10-j mezhregional'noj nauchno-prakticheskoj konferencii [Cardiology and cardiosurgery: innovative solutions - 2016 Materials of the 1oth anniversary interregional scientificpractical conference]. "Astrakhan State Medical University” 2016: 176-178 (In Russ.).
9. Chichkova M.A., Svetlichkina A.A., Dorontsev A.V. The influence of adaptive sports on reserve indices of cardiovascular system among patients with sensorineural hearing loss of the I II degrees. Chelovek. Sport. Medicina. 2018; 18(4): 117-122 (In Russ.).

10. Chichkova M.A., Svetlichkina A.A. The way of cardiovascular system complex estimation among disabled people. Patent [Patent] RUS 2672934 19.09.2017 (In Russ.)

11. Zinchuk N.A., Yermolina N.V., Dorontsev A.V., Svetlichkina A.A. Study of therapeutic physical exercise impact on the functional status of elderly women. Advances in Gerontology. 2019; 9(1): 98100 (In Engl.).

12. Balabinis C.P., Psarakis C.H., Moukas M., Vassiliou M., Behrakis P.K. Early phase changes by concurrent endurance and strength training. $\mathrm{J}$ Strength Cond. Res. 2003; 17(2): 393-401.

\section{Submitted: 12.08.2019}

Author's information:

Aleksey V. Dorontsev - Candidate of Pedagogics, Associate Professor, Astrakhan State Medical University, 414000, Russia, Astrakhan, Bakinskaya str., House 121, e-mail: aleksandr.doroncev@rambler. ru

Anastasiya A. Svetlichkina - Post-graduate, Astrakhan State Medical University, 41400o, Russia, Astrakhan, Bakinskaya str., House 121, e-mail: doronceva@rambler.ru

Nina A. Zinchuk - Candidate of Pedagogics, Associate Professor, Astrakhan State University, 414062, Russia, Astrakhan, Tatischev str., House 20a, e-mail: nina-zinchuk@mail.ru

Natalya V. Yermolina - Candidate of Pedagogics, Associate Professor, Astrakhan State University, 414062, Russia, Astrakhan, Tatischev str., House 20a, e-mail: tomara-72_64@mail.ru 